troduction. In the other two experiments the quantities were 10 and 9.5 grms. respectively ( $15+$ and 146 grians), and it was fonnd that these quantities were not wholly eliminated by the kidneys, a part probably passing out of the body by the intestinal canal. So that it wonld appear that the lidneys have only the power of exereting phosphates up to a eertain maximum rate; that, therefore, when large quantities are present in the blood, their excretion is very gradually accomplished, and when the quantities are very exeessive, the intestinal canal is brought in to aid the kidneys.-Glasgow Med. Journ., May, 1872, froin Virchow's Archiv, December, $18 \pi 1$.

4. Orea in the Animal Body,-Gscherbuex has examined almost every tissue in the body for urea, and finds it universally distributed, exeept in the muscles, in whieh it is never present.

5. Investigations on Low Organisms.-Prof. Rindfleisch, of Bonn, has published (Tirchow's Archiv, December, 1871) some investigations on this subjeet which are of great interest, and whieh, when further proseented, are likely to lead to important results. His objeet has been to find a method by which he eonld cultivate fungi, in sueh a manner as that, while the substance is exposed to the air, it should be proteeted from all impurities. With this view he prepares a square microscopic eover-glass, by placing a small drop of wax at each corner, so that when the eover-glass is placed on the slide it is supported as on four pillal's of hard wax. 'T'he substance to be observed is placed in the eentre of a well-eleaned glass slide, and the eover-glass is then placed on it, being afterwards slightly fixed by wax at the four corners. By this nleans the substance to be investigated is situated beneath the centre of the cover-glass, aud around it, under the eover-glass, is a thin zolle of air. But this zone is so thin that it will be perfectly still, and no dust will be earried in by currents, while at the same time there is nothing to interfere with any chemical change which unay oceur between the air and the growing fungus. This method being devised, the author proposes to sow rarious substanees with the spores of different fingi, and observe the results. It is to be observed that during the intervals of observation tle preparations are kept in a moist atmosphere. 'l'le first observations lecorded were made with mould fungus. $\boldsymbol{A}$ portion of apple pulp was placed on a slide, aud tlis sown with spores of the fungus found in rotten apples (bulrytis cinerea) and the growth of the fungus was seen to take place in the most beautiful manner. It was remarked that, strangely enough, though the mycelium of the fungus grew continuously, the spores were only produced at night. 'I'he favus fungus (achorion Schonleinii) was next subjeeted to.observation. A favus erust was moistened with a drop of distilled water, and treated as above. 'The fuugus grew, but its growth was comparatively slow, threals glowing out from the moistened erust and producing spores. The spores wel'e rod-shaped as they were formed, but on the addition of a drop of watel they swelled up and became globular. The same fungus was also enltivated on a portion of the fruit from plum jam, and the result was a mueh more vigoruus growth than when the lavus crust was merely moistened. 'The different parts were distinctly larger and the growth rieher, so that the anthor describes it as quite a tropical growth of the fungus. We are glad that the autbor promises still further observations of this interesting nature.-Glasyow Med. Joum., May, 1872.

6. On the Occurrence of Fungi in the Blood of healthy Men.-Dr. LostonFER has published some observations made by him on blood talen from the finger of healtliy men, with precautions to iusure against contamination. A single drop was placed on a slide and preserved from evaporation by being kept in a noist eluamber. During the first two days nothing noteworthy was remarked; but on the third day there appeared pale globular granules grouped together to the number of two or four, up to twelve. On the fourth day these groups had enlar'ged both by inerease in size in the individual granules, and in. erease in the number of granules forming the groups. At the same time the granules had somewhat changed their shape, beeoning from globular more 
angular, so as to resemble the sarcina-form. On the fifth day the groups wcre still larger, this depending very little on increase in size of the granules, but chicfly on increase in number. As they resemble the sarcina in form, so do they also in their mode of increase as actually observed, this mode of increase being by division. They differ from the commonly known appearances of sarcina in certain points; (1) they are much smaller; (2) the groups are made up of a much larger number of individual granules; (3) they are always colourless, whereas the sarcina ventriculi has gencrally a yellow tinge. But various observers have alrcady shown that the same fungus may exist in somewhat different conditions undcr varied circumstances (see even the case of the favus fungus in the article from Virchow's Archiv, abstracted abovc), and the author has found that when Pasteur's fluid is added to thc blood in which these organisms have become developed, they become considerably larger, their angles become more marked, and they take on a yellowish tinge, so as to approach much more nearly to the better known appearances of sarcina. The author himself has no doubt as to their identity with the sarcina ventriculi. These organisms are not present in the blood while in the vessels, but these experiments scem to show, that in the majority of cases at least, their germs are there present, and that when the blood is effused and left at rest, the sarcinæ may devclop. It is to be remarked that the development of the sarcinæ was not a plenomenon of the ordinary proccss of decomposition of the blood; the experiments wcrc made with special precautions against the admission of germs of baeteria. etc., and as an actual fact the sarcinge appeared beforc any signs of decomposition, or the derclopment of bacteria, so that the author seems warranted in concluding that their germs were present in the blood at the time of removil. The author then refers to various instances in whicl the occurrenee of sarcinse in other parts of the body than the stomach lias been recorded. It bas bcen observed in the lungs, and in the urine especially, and he has no doubt that in these cases the blood was the source from which the germs of the organism were derived. There is also a very stroug presumption that even in the stomach the germs are supplied by the blood.

The very remarkable fact of the development of sarcina in healthy blood has been confirmed by Dr. Ferrier, whose investigations are publislied in the Brit. Med. Journ., January 22, 1872.-Glasgow Med. Journ., May, 1872, from Stricker's Jahrbiicher, Pt. IV., 1871.

7. Precocious Development.-M. Frugat (Bagr. Aratl. Int, Blt., No. 49, 1871) gives the account of a female child who had died at the age of 5 years and 6 months, from an attack of dysentery, and at that period had attained the height of 5 feet, and a proportionate development of the bods thronghout. When six months old she had cut all the incisor tceth, when nine months old all the molars. When she had reached her eighteenth month, her catanienial discharges first made their appearance, and from that time occurred with great regularity, especially during her later years. Whilst present she exhibited an unusual degrce of liveliness. The hair of her liead was long and beantiful. The mamina prominent, external genitals well developed but devoid of hair. The pelvis was capacious. 'The condition of the internal sexual organs was not ascertained. The intellectual powers of the child, althongh for six months preceding her death she had begun to prattle, did not appear to bc any more advanced thau customary at her agc.-Centralblatt $f$. d. Medicinish Wissenschaften, Feb. 17, 1872.

1. F. C.

\section{MATERIA MEDICA AND GENERAL THERAPEUTICS AND PHARMACY.}

8. Action of Chloral Hydrate.-The author of a prize essay, presented to the Medical Society of Lyons, has observed (Lyon Medical, 1872, p. 296) that the action of chloral on animals varies according to staturc, age, and racie; old dogs resisting its action less than young or adult oues, and hounds and spaniels 